\title{
Exclusion of the Brown Marmorated Stink Bug from Organically Grown Peppers Using Barrier Screens
}

\author{
Rachelyn C. Dobson ${ }^{1}$, Mary Rogers $^{2,5}$, Jennifer L.C. Moore ${ }^{3}$, \\ and Ricardo T. Bessin ${ }^{4,6}$
}

AdDitional INDEX wORDs. Halyomorpha balys, Capsicum annuum, organic, integrated pest management, invasive pest

Summary. The brown marmorated stink bug (Halyomorpha halys) is a nonnative insect that damages vegetables and other crops in the United States. Because of the current lack of effective control options for organic growers to combat this pest, barrier screens with different mesh sizes were evaluated in their ability to exclude the brown marmorated stink bug, provide entry to beneficial species, and to produce a high percentage of marketable yield. Barrier screens with 1/6-, 1/8-, and 1/25-inch mesh sizes, along with unscreened controls, covered 'Aristotle' bell pepper (Capsicum annuum) plants at field sites in Kentucky and Tennessee in 2013-14. In Kentucky, where brown marmorated stink bug pressure was low, overshading decreased the marketable yield under dark, 1/25-inch mesh screens in 2013. Outbreaks of aphids (Aphididae) under light-colored, $1 / 25$-inch mesh plots in 2014 suggest a higher risk of secondary pests proliferating under these screens. In Tennessee, where brown marmorated stink bug pressure was higher and light colored, 1/25-inch mesh screens were tested in 2013-14, the $1 / 25$-inch mesh plots produced the highest yield, due to the general exclusion of insects and protection from sunscald. In areas with small brown marmorated stink bug populations, lighter colored, and/or wider meshes (1/8-inch or $1 / 6$-inch) may be required to allow the entry of sunlight and beneficial species. In areas with higher brown marmorated stink bug pressure, finer meshes $(1 / 25$-inch) may be appropriate to exclude larger populations of pests and to protect the crop from sunscald.

$\mathrm{T}$ The brown marmorated stink bug was first identified in the United States in Allentown, PA, in the mid-1990s (Hoebeke and Carter, 2003). Since then, it has spread to at least 42 states and two Canadian provinces (Leskey, 2014). The brown marmorated stink bug was first identified in Tennessee in 2008 and in Kentucky 2 years later (Hamilton, 2011). The brown marmorated stink bug is able to rapidly extend its range into a diverse array of climatic regions because of its ability to overwinter in human-made structures that are often actively heated in colder areas (Nielsen et al., 2008) and wide dietary range that provides this stink bug with acceptable food sources in various habitats (Lee et al., 2013a). As the populations of the brown marmorated stink bug build within invaded territories, the stink bug progresses from a household nuisance into a major agricultural pest that can inflict massive crop yield losses during outbreak years (Funayama, 2008). In Asia, where the brown marmorated stink bug is native, injury levels of
90\% on cucumber (Cucumis satious) and eggplant (Solanum melongena), $70 \%$ on sweet corn (Zea mays), 60\% on asparagus (Asparagus officinalis), and $8 \%$ on bell pepper have been reported (Fukuoka et al., 2002). Despite being targeted by several egg parasitoids and invertebrate predators in Asia (Lee et al., 2013a), the brown marmorated stink bug can be a major agricultural pest in outbreak years, potentially due to fluctuation in the populations of native natural enemies. In the United States, brown marmorated stink bug injury on sweet corn has reached $100 \%$ in some fields (Leskey et al., 2012a). Injury on other vegetable crops including pepper, tomato (Solanum lycopersicum), eggplant, and okra (Abelmoschus esculentus) has exceeded $20 \%$ in research plots (Leskey et al., 2012a). Economic damage inflicted by this new invasive stink bug is creating an urgent need for effective controls to counter it.

Both brown marmorated stink bug adults and nymphs feed on a wide range of crops, including apple (Malus domestica), peach (Prunus persica), tomato, pepper, sweet corn, soybean (Glycine max), cotton (Gossypium sp.), and field corn $(Z$. mays) (Lee et al., 2013a, 2013b; Nielsen et al., 2008; Owens et al., 2013; Zhu et al., 2012). Adult brown marmorated stink bugs overwinter under the bark of trees and feed on various types of trees after their emergence in the spring including lilac (Syringa vulgaris), maple (Acer sp.), redbud (Cercis sp.), london planetree (Platanus acerifolia), and ornamental cherry (Prunus sp.) (Leskey et al., 2012a). Generally, brown marmorated stink bugs disperse into nearby agricultural fields after the crops have flowered (Lee et al., 2014). Feeding early in the growing season on fruits and vegetables such as apple, tomato, pepper, and eggplant after flowering can cause abscission, the premature dropping of fruit from the plant (Lee et al., 2013a; Nielsen and Hamilton, 2009). Feeding that occurs later in the growing season can leave the fruit externally and internally scarred, decreasing the percentage of marketable fruit (Lee et al., 2013a; Nielsen and Hamilton, 2009). External feeding wounds may also serve as a point of entry for pathogens, such as Erwinia carotovora, that cause bacterial soft rot (Cerkauskas, 2004).

Because the brown marmorated stink bug damages crops throughout a large part of the growing season and disperses from one crop to another, the continual application of control measures is costly and time consuming to growers. The most severe economic damage to fruit crops has occurred in the eastern United States, including Maryland and West Virginia, where the brown marmorated stink bug has

\begin{tabular}{llll}
\hline $\begin{array}{l}\text { Units } \\
\text { To convert U.S. to SI, } \\
\text { multiply by }\end{array}$ & U.S. unit & SI unit & $\begin{array}{l}\text { To convert SI to U.S., } \\
\text { multiply by }\end{array}$ \\
\hline 0.4047 & $\mathrm{acre}(\mathrm{s})$ & $\mathrm{ha}$ & 2.4711 \\
0.3048 & $\mathrm{ft}$ & $\mathrm{m}$ & 3.2808 \\
2.54 & inch(es) & $\mathrm{cm}$ & 0.3937 \\
0.4536 & $\mathrm{lb}$ & $\mathrm{kg}$ & 2.2046 \\
0.0254 & $\mathrm{mil}$ & $\mathrm{mm}$ & 39.3701
\end{tabular}


been established longer (Leskey et al., 2012a, 2012b). During the outbreak of 2010 , brown marmorated stink bug damage inflicted on apple cost the industry over \$37 million, along with a 4 -fold increase in pesticide applications (Quarles, 2014). Vegetable crops such as bean (Phaseolus vulgaris), tomato, pepper, and eggplant are affected (Kuhar et al., 2012) and sweet corn seems to be a preferred vegetable host. Feeding on corn kernels and beans can cause these structures to shrivel and discolor (Kuhar et al., 2012; Owens et al., 2013). Feeding on tomato and pepper fruits produces a light-colored blemish at the feeding sites and causes a white, corky texture to form underneath the externally injured areas (Kuhar et al., 2012). Native stink bug species, including the green stink bug (Chinavia hilaris) and the brown stink bug (Euschistus servus), cause similar types of injury on a broad range of plants that are targeted by the brown marmorated stink bug, including vegetables crops such as tomato (Kamminga et al., 2009, 2012). Management strategies developed for the brown marmorated stink bug may also help reduce crop injury caused by these native stink bugs.

Organic growers have limited options of National Organic Programcompliant products to combat the

\footnotetext{
This publication is a part of the thesis, Mechanical Exclusion and Biological Control Strategies For the Invasive Brown Marmorated Stink Bug, Halyomorpha halys (Hemiptera: Pentatomidae), published by Rachelyn Dobson at the University of Kentucky in 2015.

We thank the U.S. Department of Agriculture, Organic Research and Extension Initiative for their funding and support of this research. The Tennessee authors would like to thank Lee Ellis, Cody Fust, Justin Hawkersmith, Caleb Johnson, and Bill Lively for their invaluable help with field work; and Annette Wszelaki for her guidance. The Kentucky authors would like to thank Chelsea Berish, Waydon Yates, Sarah Detraz, and the staff of the University of Kentucky Horticulture Research Farm for their assistance with field trials.
}

${ }^{1}$ Graduate Research Assistant, Department of Entomology, University of Kentucky, S-225 Agricultural Science Center North, Lexington, KY 40546

${ }^{2}$ Postdoctoral Research Associate, Department of Plant Sciences, University of Tennessee, Institute of Agriculture, Knoxville, TN 37996

${ }^{3}$ Research Specialist, Department of Plant Sciences, University of Tennessee, Institute of Agriculture, Knoxville, TN 37996

${ }^{4}$ Extension Professor, Department of Entomology, University of Kentucky, S-225 Agricultural Science Center North, Lexington, KY 40546

${ }^{5}$ Current address: Assistant Professor in Department of Horticultural Science at the University of Minnesota, 438 Alderman Hall, 1970 Folwell Avenue, Saint Paul, MN 55108

${ }^{6}$ Corresponding author. E-mail: rbessin@uky.edu. brown marmorated stink bug and these are often less effective than their conventional counterparts. Ideally, a diverse range of control tactics including cultural and biological control need to be available to provide growers with ample options. Organic control tactics currently being explored include using insectary plantings to bolster natural enemies (Rice et al., 2014), using trap crops to lure the brown marmorated stink bug away from valuable cash crops (Lee et al., 2013a), and exploiting biological control agents that are native or imported (Talamas et al., 2015).

This study focused on the use of plastic mesh barrier screens to physically exclude the brown marmorated stink bug and other stink bug pests from crops. Exclusion has been used in other agricultural integrated pest management (IPM) programs by constructing screen houses that cover the crop in the field (Ausher, 1997). These screen houses have been widely adopted and proven to be economically feasible in Israel, where they are incorporated into IPM programs to physically exclude the silverleaf whitefly (Bemisia tabaci) from tomato (Taylor et al., 2001). Not only would screens need to exclude target pests, but ideally they would allow for some movement of natural predators through the mesh to prevent secondary pest outbreaks under the screens. However, netting does increase shading of plants and may reduce yields (Ajwang et al., 2002). Studies investigating the shading effects of barrier screens on specific pepper varieties, including Dolmi (Kitta et al., 2014) and yellow lantern chili (Capsicum chinense; Jaimez and Rada, 2006) concluded that the pepper plants actually compensated for the shading effects and produced fruit that was not significantly different from fruit produced in unscreened counterparts. These studies suggest pepper may be an ideal crop to protect from stink bugs with barrier screens because of their shading compensation and were, therefore, selected as the study crop for these screen trials. Screens were tested in organically managed, pepper crop settings in Kentucky and Tennessee, allowing the study to compare results from regions that have supported brown marmorated stink bug populations for different timeframes.

\section{Materials and methods}

All field studies were conducted during the summer growing seasons of 2013 and 2014. Untreated 'Aristotle' bell pepper seeds (Seedway, Hall, NY) were grown to serve as the test crop. New seeds were purchased each year. The resulting pepper plants were transplanted onto raised pairs of plastic-covered beds (1-mil thick; Pliant Corp., Chippewa Falls, WI), with underlying drip tape (10-mil thick, 12-inch emitter, T-Tape; DripWorks, Willits, CA), in the fields in staggered, double rows on each raised, plastic bed. The double rows of pepper plants were separated by 18 inches and plants within a row were separated by 15 inches. The ground between the plastic-covered beds was covered in landscape fabric (Professional Landscape Fabric; Greenscapes, Jamesville, $\mathrm{NY}$ ) and secured to the ground with 6-inch sod stakes, to suppress weeds. The screens were arranged in the fields in treatment blocks, with the first block covering the end of the raised beds, followed by three or four treatment blocks, spaced $6 \mathrm{ft}$ apart. Each plot enclosed a section of a single plastic bed pair. Five treatment blocks were used at the Kentucky site and four were used at the Tennessee site. Screened treatments included a 1/6-inch, 1/8-inch (Industrial Netting, Minneapolis, $\mathrm{MN}$ ), and white $1 / 25$-inch fine mesh, 30\% woven shadecloth (Green. Tek, Janesville, WI). At the Kentucky site in 2013, black 1/25-inch mesh screens (Dewitt, Sikeston, MO) were tested in place of the white screens, as available quantities of the white $1 / 25$-inch mesh permitted testing in only one location. Throughout data entry and analysis at both study sites, the term "plot" referred to the treatment units in general whereas "cage" designated only screened treatments.

KentUCKY sITE. All greenhouse plantings and field trials were carried out at the University of Kentucky Horticultural Research Farm in Lexington (lat. $37^{\circ} 58^{\prime} 23.06^{\prime \prime} \mathrm{N}$, long. 84 $32^{\prime} 8.18^{\prime \prime} \mathrm{W}$ ) in the organically certified section. During Apr. 2013 and 2014, bell pepper seeds were grown in 72-cell trays in $0.1 \mathrm{~N}-0.02 \mathrm{P}-0.04 \mathrm{~K}$ potting mix (Organic Choice Potting Mix; Miracle-Gro, Marysville, $\mathrm{OH}$ ), following standard practices in the organic greenhouses on the farm. Before the construction of plastic-covered, raised growing beds 
in the field, $4 \mathrm{~N}-0.9 \mathrm{P}-3.3 \mathrm{~K}$ organic fertilizer (Fertrell Co., Bainbridge, PA) was incorporated into the 0.2 -acre field site to a depth of 6 inches at a rate of $80 \mathrm{lb} /$ acre $\mathrm{N}$ using a rotary tiller. Four pairs of 120-ft-long plastic-covered beds with underlying drip tape were laid using a plastic mulch layer. Pairs of rows were separated by 48 inches while rows within a pair were separated by 18 inches. The bell pepper plants were transplanted on the plastic-covered beds using a water-wheel setter on 14 May 2013 and on 20 May 2014. The bases of the peppers were covered with soil to prop the plants off the black plastic.

Cage frames were composed of two, overlapping pieces of 15 - $\mathrm{ft}$-long, $1 / 5$-inch diameter reinforcing rebar, each end driven into the plastic-covered row to a depth of 8 inches, creating a domed shape. Electrical wire was wrapped around the top of the cage at the intersection of the rebar pieces for stability and was also wrapped around the circumference of the frame to keep the screens from encroaching on the peppers. Screen materials were cut into $16 \times 14$-ft pieces and draped over the cage frames. The screens were held to the ground by covering excess netting with 14 paving stones $(8 \times 6$ by 3 inches) spaced $\approx 18$ inches apart around the exterior of the cage. Each cage measured $6.5 \times 6.5 \mathrm{ft}$, was $\approx 4.5 \mathrm{ft}$ in height, and covered 24 pepper plants. Control plots did not contain a cage or frame but were delineated by research flags at their corners. Screens were constructed in the field on 23 May 2013 and 27 May 2014 before the initiation of flowering. The delay in the screening of plots likely did not influence the chance of trapping stink bugs inside the cages due to the low probability of their presence before flowering (Lee et al., 2013a).

To monitor beneficial insects, one yellow $15 \times 30-\mathrm{cm}$ sticky card (IPM Corn Rootworm Card; Great Lakes IPM, Vestaburg, MI) was secured with binder clips on an 18-inch wooden stake and was collected and replaced in each plot weekly. The stakes with yellow sticky cards were set in the middle of one plastic-covered bed within each plot, with the card positioned parallel to the rows of peppers. Collected yellow sticky cards were covered in thin plastic film, labeled with the appropriate collection date and plot, and stored in a cooler until they could be analyzed. All beneficial insects on the yellow sticky cards were identified to the family level. Visual searches within the plots were also conducted weekly to detect the presence of stink bugs. During these searches, the four middle plants in each plot were thoroughly examined and the species and life stage of any stink bugs found in the plots were recorded. Though sweep net sampling is more reliable for measuring the density of brown marmorated stink bug before they drop to the ground (Quarles, 2014), the limited space inside the plots and the risk of damaging the fruit lead to visual counts being employed instead for this study.

The plots were harvested three times during each year to assess the quality and quantity of peppers from each plot. The peppers from each plot were first counted and weighed together. Then, marketable peppers were divided into size categories according to the U.S. Department of Agriculture size categories of "Fancy," "No. 1," and "No. 2" (USDA, 2005). Culled, unmarketable peppers were counted and assessed for injury. Any incidence of sunscald and chewing insect injury was documented. The number of stink bug feeding sites on each pepper was recorded to determine damage severity. Fruit was harvested on 15-17 July, 30 July, and 12 Aug. 2013; and 8-10 July, 22-23 July, and 12-13 Aug. 2014. To reduce the movement of insects into the plots during harvest, researchers kept the cages closed except when entering and exiting the plots.

Tennessee site. Field trials were conducted at the Organic Crops Unit of the East Tennessee AgResearch and Education Center in Knoxville (lat. $35^{\circ} 52^{\prime} 48.00^{\prime \prime} \mathrm{N}$, long. $\left.83^{\circ} 55^{\prime} 47.95^{\prime \prime} \mathrm{W}\right)$. In 2013 , bell pepper seeds were sown in a greenhouse in 128-cell plug trays (Griffin Greenhouse Supply, Knoxville, TN) using $0.02 \mathrm{~N}-0.03 \mathrm{P}-0.06 \mathrm{~K}$ potting mix (Premium Lite Organic Grow Mix; McEnroe Organic Farm, Millerton, $\mathrm{NY}$ ) and then potted up to 50 -cell plug trays. In 2014 , seeds were sown in 72 -cell plug trays. Before the construction of plastic-covered, raised growing beds in the field, the field site was top-dressed with $8 \mathrm{~N}-2.2 \mathrm{P}-$ $4.2 \mathrm{~K}$ organic poultry litter fertilizer (Nature Safe Natural and Organic Fertilizers, Cold Spring, KY) at a rate of $90 \mathrm{lb} /$ acre $\mathrm{N}$. The soil was rototilled to a depth of 6 inches using a rotary tiller (Bush Hog, Selma, AL) and a compact tractor (B Series; Kubota Tractor Corp., Torrance, CA). Four pairs of plastic-covered rows (1-mil thick), with underlying drip tape (10-mil thick, 12-inch emitters, T-Tape), were laid to a length of $150 \mathrm{ft}$. Pairs of rows were separated by 36 inches and rows were separated by 24 inches within a pair. Pepper plants were transplanted by hand on 27 May 2013 and 7 May in 2014.

Cage frames were constructed using $1 / 2$-inch diameter metal electrical conduit and $1 / 2$-inch polyvinylchloride elbows, with an insertion of $1 / 2$-inch rubber hosing to secure the metal conduit. The cages were $4 \mathrm{ft}$ high, $5 \mathrm{ft}$ long, and $6 \mathrm{ft}$ wide. Unscreened plots were delineated by the same cage frames as the screened plots. The cages were constructed on 8 July 2013 and 24 June 2014 and each cage covered 13-15 plants.

To monitor for pests and beneficial insects inside the covered and open plots, yellow sticky cards on wooden stakes were placed in the center of each plot and replaced weekly for 6 weeks. Yellow sticky cards were labeled, placed in clear plastic bags, and frozen until they could be analyzed. Insects on sticky cards were identified to family and all brown marmorated stink bug within the plots were counted on each harvest date.

The plots were harvested on 30 July, 13 Aug., 27 Aug., and 10 Sept. 2013; and on 17 July, 31 July, 14 Aug., 28 Aug., 10 Sept., and 19 Sept. 2014. The harvests were analyzed in the same way as the Kentucky sites, though peppers that contained stink bug and other types of injury were assessed and weighed separately. Damage recorded on peppers included, but was not limited to, zippering, cracking, splitting, soft rots and bacterial spots (E. carotovora), and fungal diseases [e.g., early blight (Alternaria solani) and gray mold (Botrytis cinerea)].

Data analysis. Data collected during pepper harvests (including the number, weight, and sizes of peppers and the instances of various types of damage) along with data collected from yellow sticky cards (numbers of sampled beneficial and pest insects) were compared among treatments in SAS (version 9.3; SAS Institute, Cary, NC). A mixed model analysis of variance was performed on the data with year and treatment classified as fixed 
effects and block and block by year designated as random effects (Saxton and Auge, 2014). A Fisher's least significant difference means separation was used to determine significant differences between treatment effects at $\alpha=0.05$ and test the null hypothesis that treatment effects would not be significantly different among treatment plots.

\section{Results}

Kentucky site. Though a black, fine mesh was tested in 2013 and a white, fine mesh was tested in 2014, their individual effects on the resultant pepper crops and their exclusion of natural enemies were mostly consistent both years. Therefore, the fine-mesh treatments were combined for analysis in Kentucky so they could be more easily compared with data from the Tennessee site, which tested white, fine mesh both years.

Beneficial insects identified on the yellow sticky cards included lady beetles (Coccinellidae), hover flies (Syrphidae), green lacewings (Chrysopidae), damsel bugs (Nabidae), damselflies (Order Odonata, Suborder Zygoptera), minute-pirate bugs (Anthocoridae), long-legged flies (Dolichopodidae), big-eyed bugs (Geocoris), ground beetles (Carabidae), and spined soldier bug (Podisus maculiventris). Significantly more beneficial insects were identified in the unscreened plots compared with the screened plots and significantly fewer beneficial insects were identified in the fine-mesh plots than in the other plots (Table 1). Significantly higher percentages of peppers with stink bug injury were found in the $1 / 8$-inch mesh and unscreened plots (Table 2). The highest number of stink bug feeding sites on peppers was observed in the unscreened and 1/8-inch mesh plots and the lowest was observed in the 1/6-inch and finemesh plots. The highest incidence of insect chewing injury was observed in the unscreened and 1/6-inch mesh plots. Significantly more sunscald was observed in the unscreened plots when compared with the screened plots.

No stink bugs were observed in the Kentucky plots during weekly searches in 2013. Most of the stink bugs in 2014 were identified inside the $1 / 8$ - and 1/6-inch mesh plots, with three stink bugs identified in both treatment plots. A second instar, third instar, and adult green stink bug were identified in the $1 / 8$-inch mesh plots and a third instar green stink bug and two adult brown stink bugs were identified in the $1 / 6$-inch mesh plots. One adult brown marmorated stink bug was identified in the unscreened plots and no stink bugs were identified in the fine-mesh plots.

The total pepper yield in numbers and weight in Kentucky was significantly higher in the unscreened plots compared with the screened plots (Table 4). Though the number of marketable peppers was not significantly different among treatments, the percentage of marketable peppers was significantly higher in the screened plots compared with the unscreened plots. No significant differences were observed among treatments for the numbers of fancy or number 2 grade peppers (Table 5). There were significantly more number 1 grade peppers harvested from the unscreened plots when compared with the screened plots.

Tennessee site. Insects identified on the yellow sticky cards included brown marmorated stink bug, fleahoppers (Halticus), flea beetles (Chrysomelidae), leafhoppers (Cicadellidae), lygus bugs (Lygus sp.), lady beetles, green lacewings, pollinators, big-eyed bugs, damsel bugs, carabids, and parasitoids. Parasitoids on the yellow sticky cards were not identified to family, though parasitoids from the genera Ooencyrtus, Telenomus, and Trissolcus were identified in the same location during a parallel study surveying egg parasitoids of the brown marmorated stink bug (Ogburn et al., unpublished data). Significantly fewer pest and beneficial insects were identified in the fine-mesh plots when compared with the other treatment plots (Table 1). Significantly more beneficial insects were identified in the $1 / 8$-inch mesh and unscreened plots though beneficial insects identified in the 1/6and $1 / 8$-inch mesh plots were not significantly different from each other.

Most of the peppers with stink bug damage in Tennessee were found in the unscreened, $1 / 6-$, and $1 / 8$-inch mesh plots (Table 2 ). The percentages of peppers with stink bug damage among these three treatment plots were not significantly different and the percentages identified in the $1 / 6$-inch and fine-mesh plots were not significantly different. The same trend was observed for stink bug injury severity with the exception of the $1 /$ 8 -inch mesh plots that were not significantly different from the $1 / 6$-inch and fine-mesh plots. There were no significant differences in the number of peppers that were culled for defects other than stink bug injury among the treatment plots.

Significantly, more brown marmorated stink bug adults were identified in the unscreened plots in Tennessee and their numbers were not significantly different among screened plots (Table $3)$. There were no significant differences for the total numbers or weight of peppers harvested from the treatment plots in Tennessee (Table 4). The highest numbers of marketable peppers were harvested from the 1/6inch and fine-mesh plots. By percentage, more marketable peppers were harvested from the fine-mesh plots. Significantly, fewer fancy grade peppers were harvested from the unscreened plots when compared with the screened plots (Table 5). Significantly, more number 1 grade peppers were harvested from the fine-mesh plots and fewer number 1 grade peppers were harvested from the unscreened plots. No significant differences were observed among treatments for the number 2 grade peppers.

\section{Discussion}

The fine-mesh plots, in both geographic locations, excluded insects, including beneficial and pest species. Although the exclusion of pest insects is a positive quality, the exclusion of beneficial insects could allow a secondary pest outbreak to occur if small pests are able to enter the plots. An outbreak of aphids did occur under the fine-mesh plots at the Kentucky site in 2014. These pests were not observed on the pepper plants before cage construction and their small size could have allowed them to enter the plots directly through the fine mesh. This indicates that the fine-mesh screens could potentially harbor small-sized pests from natural enemies, allowing the pests to proliferate and cause damage to crops. The medium size screens ( $1 / 6$ - and $1 / 8$-inch) at the Tennessee site were unable to exclude pests when compared with the control plots. Because this trend was observed at the site with greater pest pressure, it suggests that medium size screens are unable to exclude pests in areas with high pest densities. 
Table 1. Mean number of pest and beneficial insects identified weekly on yellow sticky cards placed in screened field plots and unscreened control plots of 'Aristotle' bell pepper at the University of Kentucky Horticulture Research Farm and the University of Tennessee Organic Crops Unit during 2013 and 2014.

\begin{tabular}{|c|c|c|c|}
\hline \multirow[b]{2}{*}{ Treatment $^{\mathrm{z}}$} & \multirow{2}{*}{$\frac{\text { Kentucky }^{\mathrm{y}}}{\text { Beneficial insects (no.) }^{\mathrm{w}}}$} & \multicolumn{2}{|c|}{ Tennessee $^{\mathrm{x}}$} \\
\hline & & Pest insects (no.) ${ }^{\mathrm{v}}$ & Beneficial insects (no.) ${ }^{\mathrm{u}}$ \\
\hline $1 / 25$-inch fine mesh & $0.4 \mathrm{C}^{\mathrm{t}}$ & $48 \mathrm{~B}$ & $39 \mathrm{C}$ \\
\hline $1 / 8$-inch mesh & $2.8 \mathrm{~B}$ & $91 \mathrm{~A}$ & $67 \mathrm{AB}$ \\
\hline 1/6-inch mesh & $3.2 \mathrm{~B}$ & $94 \mathrm{~A}$ & $58 \mathrm{~B}$ \\
\hline No screen & $9.4 \mathrm{~A}$ & $95 \mathrm{~A}$ & $66 \mathrm{~A}$ \\
\hline$P ; \mathrm{df}$ (numerator, denominator); $\mathrm{F}$ & $P<0.001 ; 3,471 ; 30.55$ & $P<0.001 ; 3,193.3 ; 18.25$ & $P<0.001 ; 3,193.1 ; 23.45$ \\
\hline $\begin{array}{l}{ }^{2} 1 \text { inch }=2.54 \mathrm{~cm} . \\
\text { yellow sticky cards were deployed weekly in } \\
\text { "Yellow sticky cards were deployed weekly in } \\
\text { "Lady beetles, hover flies, green lacewings, } \\
\text { "Fleahoppers, flea beetles, leafhoppers, and } \\
\text { "Lady beetles, green lacewings, big-eyed bu }\end{array}$ & $\begin{array}{l}\text { m } 6 \text { June to } 22 \text { Aug. } 2013 \text { an } \\
\text { m } 15 \text { July to } 29 \text { Aug. } 2013 \text { an } \\
\text { gs, damselflies, minute-pirate } \\
\text { bugs, carabid beetles, hymen } \\
\text { SAS Institute) and Fisher's leas } \\
\text { Untransformed means are re } \\
01 \text {. }\end{array}$ & $\begin{array}{l}\text { June to } 28 \text { Aug. } 2014 \text {. } \\
\text { July to } 14 \text { Aug. } 2014 \text {. } \\
\text {-legged flies, big-eyed bugs, groun } \\
\text { Irasitoids, and pollinators. } \\
\text { nt difference means separation wer }\end{array}$ & $\begin{array}{l}\text { s, and spined soldier bug. } \\
\text { eed on the data set. Tennes } \\
\text { etter are not significantly di }\end{array}$ \\
\hline
\end{tabular}

Table 2. Summary of mean stink bug injury and other causes of unmarketable 'Aristotle' peppers harvested from screened field plots and unscreened control plots at the University of Kentucky Horticulture Research Farm and the University of Tennessee Organic Crops Unit during 2013 and 2014.

\begin{tabular}{|c|c|c|c|c|c|c|c|}
\hline \multirow[b]{2}{*}{ Treatment $^{\mathrm{z}}$} & \multicolumn{4}{|c|}{ Kentucky $^{\mathrm{y}}$} & \multicolumn{3}{|c|}{ Tennessee $^{\mathrm{x}}$} \\
\hline & $\begin{array}{c}\text { Harvest } \\
\text { with SB } \\
\text { injury (\%) }\end{array}$ & $\begin{array}{c}\text { Severity of } \\
\text { SB injury } \\
(\text { no. })^{w}\end{array}$ & $\begin{array}{l}\text { Peppers with } \\
\text { chewing } \\
\text { injury (no.) }\end{array}$ & $\begin{array}{c}\text { Peppers } \\
\text { with sunscald } \\
\text { (no.) }\end{array}$ & $\begin{array}{c}\text { Harvest } \\
\text { with SB } \\
\text { injury (\%) }\end{array}$ & $\begin{array}{c}\text { Severity of } \\
\text { SB injury } \\
(\%)^{\mathbf{v}}\end{array}$ & $\begin{array}{c}\text { Other culls } \\
(\text { no. })^{\mathrm{u}}\end{array}$ \\
\hline $1 / 25$-inch fine mesh & $0.6 \mathrm{C}^{\mathrm{t}}$ & $7.4 \mathrm{C}$ & 3.0 & $0.3 \mathrm{~B}$ & $11.6 \mathrm{~B}$ & $7.4 \mathrm{~B}$ & 5.3 \\
\hline $1 / 8$-inch mesh & $4.3 \mathrm{AB}$ & $32.9 \mathrm{AB}$ & 3.2 & $0.9 \mathrm{~B}$ & $20.6 \mathrm{~A}$ & $12.8 \mathrm{AB}$ & 5.9 \\
\hline 1/6-inch mesh & $2.1 \mathrm{BC}$ & $13.1 \mathrm{BC}$ & 4.0 & $2.4 \mathrm{~B}$ & $18.0 \mathrm{AB}$ & $12.5 \mathrm{AB}$ & 6.1 \\
\hline No screen & $6.6 \mathrm{~A}$ & $43.5 \mathrm{~A}$ & 5.3 & $8.0 \mathrm{~A}$ & $22.5 \mathrm{~A}$ & $21.6 \mathrm{~A}$ & 7.6 \\
\hline $\begin{array}{l}P ; \mathrm{df} \text { (numerator, } \\
\quad \text { denominator); } \mathrm{F}\end{array}$ & $\begin{array}{c}P<0.01 \\
3,110 ; 5.03\end{array}$ & $\begin{array}{c}P<0.01 \\
3,110 ; 5.13\end{array}$ & $\begin{array}{c}P=0.09 ; \\
3,102.3 ; 2.24\end{array}$ & $\begin{array}{c}P<0.01 \\
3,110 ; 7.94\end{array}$ & $\begin{array}{c}P=0.04 \\
3,131 ; 2.90\end{array}$ & $\begin{array}{c}P=0.04 \\
3,131 ; 2.94\end{array}$ & $\begin{array}{c}P=0.77 \\
3,137 ; 0.38\end{array}$ \\
\hline
\end{tabular}

$\mathrm{SB}=$ stink bug.

${ }^{\mathrm{z}} 1$ inch $=2.54 \mathrm{~cm}$

${ }^{y}$ Harvests conducted 15-17 July, 30 July, and 12 Aug. 2013 and on 8-10 July, 22-23 July, and 12-13 Aug. 2014

${ }^{x}$ Harvests conducted 30 July, 13 Aug., 27 Aug., and 10 Sept. 2013 and on 17 July, 31 July, 14 Aug., 28 Aug., 10 Sept., and 19 Sept. 2014

"Number of feeding sites per treatment.

vercent injury per treatment.

"Including but not limited to zippering, cracking, splitting, soft rots and bacterial spots, and fungal diseases (e.g., early blight and gray mold); Number per treatment.

${ }^{t}$ Mixed model analysis of variance in SAS (version 9.3; SAS Institute) and Fisher's least significant difference means separation were performed on the data set. Due to unequal variance, the percentage of peppers with stink bug injury and the percentage of stink bug injury per treatment were arcsine square root transformed. Untransformed percentages are reported. Values within a column followed by the same letter are not significantly different; lowercase letters $=P<0.05$, uppercase letters $=P<0.01$.

Table 3. Mean number of stink bug species and life stages identified on 'Aristotle' bell pepper plants grown in screened field plots and unscreened control plots at the University of Tennessee Organic Crops Unit, 2013 and 2014.

\begin{tabular}{|c|c|c|c|c|c|}
\hline Treatment $^{\mathrm{z}}$ & $\begin{array}{c}\text { BMSB } \\
\text { adults (no.) }\end{array}$ & $\begin{array}{c}\text { BMSB } \\
\text { nymphs (no.) }\end{array}$ & $\begin{array}{c}\text { BMSB adults } \\
\text { and nymphs (no.) }\end{array}$ & $\begin{array}{c}\text { BMSB egg masses } \\
\text { (no.) }\end{array}$ & $\begin{array}{c}\text { Brown stink bug adults } \\
\text { (no.) }\end{array}$ \\
\hline $1 / 25$-inch $^{\mathrm{y}}$ fine mesh & $0.00 \mathrm{~B}^{\mathrm{y}}$ & 0.08 & $0.08 \mathrm{~B}$ & 0.00 & 0.05 \\
\hline $1 / 8$-inch mesh & $0.00 \mathrm{~B}$ & 0.10 & $0.10 \mathrm{~B}$ & 0.03 & 0.00 \\
\hline $1 / 6$-inch mesh & $0.03 \mathrm{~B}$ & 0.08 & $0.10 \mathrm{~B}$ & 0.00 & 0.03 \\
\hline No screen & $0.38 \mathrm{~A}$ & 0.15 & $0.53 \mathrm{~A}$ & 0.00 & 0.00 \\
\hline $\begin{array}{l}P ; \mathrm{df} \text { (numerator, } \\
\text { denominator); } \mathrm{F}\end{array}$ & $\begin{array}{c}P<0.001 ; \\
3,132 ; 11.16\end{array}$ & $\begin{array}{c}P=0.14 ; \\
3,132 ; 6.72\end{array}$ & $\begin{array}{c}P<0.001 ; \\
3,132 ; 12.19\end{array}$ & $\begin{array}{c}P=0.18 \\
3,132 ; 1.67\end{array}$ & $\begin{array}{c}P=0.80 \\
3,132 ; 0.34\end{array}$ \\
\hline
\end{tabular}

$\mathrm{BMSB}=$ brown marmorated stink bug.

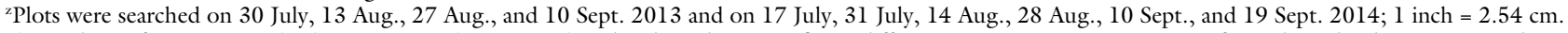

${ }^{\mathrm{x}} \mathrm{An}$ analysis of variance in SAS (version 9.3, SAS Institute) and Fisher's least significant difference means separation were performed on the data. Means within a column followed by the same letter are not significantly different; lowercase letters $=P<0.05$, uppercase letters $=P<0.01$.

The fine-mesh plots in both locations were able to reduce stink bug injury inflicted on the peppers. Stink bug injury that occurred underneath the medium size screens, especially for the $1 / 8$-inch mesh screens, could be attributed to the entry of second and third instar stink bugs through the screens that are subsequently trapped inside after they grow. Though visual identification of stink bugs inside the plots was rare at both sites, most of the stink bugs identified at the Kentucky site were found in the medium size screen plots. The presence of stink bug nymphs in the medium size screen plots could also be due to the exclusion of the relatively larger natural enemies 
Table 4. Mean total and marketable yield of 'Aristotle' bell peppers harvested from screened field plots and unscreened control plots at the University of Kentucky Horticulture Research Farm and the University of Tennessee Organic Crops Unit during 2013 and 2014.

\begin{tabular}{|c|c|c|c|c|c|c|c|c|}
\hline \multirow[b]{2}{*}{$\underline{\text { Treatment }}^{\mathrm{z}}$} & \multicolumn{4}{|c|}{ Kentucky ${ }^{\mathrm{y}}$} & \multicolumn{4}{|c|}{ Tennessee $^{\mathrm{x}}$} \\
\hline & $\begin{array}{c}\text { Total yield } \\
\text { (no.) }\end{array}$ & $\begin{array}{c}\text { Total yield } \\
(\mathrm{kg})^{\mathrm{z}}\end{array}$ & $\begin{array}{l}\text { Marketable } \\
\text { yield (no.) }^{\text {w }}\end{array}$ & $\begin{array}{c}\text { Marketable } \\
\text { yield (\%) }\end{array}$ & $\begin{array}{c}\text { Total } \\
\text { yield }^{\mathrm{x}} \text { (no.) }\end{array}$ & $\begin{array}{c}\text { Total } \\
\text { yield }^{\mathrm{w}}(\mathrm{kg})\end{array}$ & $\begin{array}{l}\text { Marketable } \\
\text { yield (no.) }\end{array}$ & $\begin{array}{c}\text { Marketable } \\
\text { yield (\%) } \\
\end{array}$ \\
\hline $1 / 8$-inch mesh & $47.4 \mathrm{~B}$ & $17.3 \mathrm{~B}$ & 36.4 & $76.6 \mathrm{~A}$ & 25.7 & 3.5 & $14.9 \mathrm{~B}$ & $55.0 \mathrm{~B}$ \\
\hline 1/6-inch mesh & $46.7 \mathrm{~B}$ & $17.4 \mathrm{~B}$ & 34.8 & $75.0 \mathrm{~A}$ & 28.2 & 4.1 & $16.9 \mathrm{AB}$ & $55.7 \mathrm{~B}$ \\
\hline No screen & $61.5 \mathrm{~A}$ & $22.5 \mathrm{~A}$ & 41.3 & $66.2 \mathrm{~B}$ & 31.8 & 3.7 & $15.6 \mathrm{~B}$ & $45.9 \mathrm{~B}$ \\
\hline
\end{tabular}

${ }^{\mathrm{z}} 1$ inch $=2.54 \mathrm{~cm}, 1 \mathrm{~kg}=2.2046 \mathrm{lb}$.

yHarvests conducted 15-17 July, 30 July, and 12 Aug. 2013 and on 8-10 July, 22-23 July, and 12-13 Aug. 2014.

${ }^{x}$ Harvests conducted 30 July, 13 Aug., 27 Aug., and 10 Sept. 2013 and on 17 July, 31 July, 14 Aug., 28 Aug., 10 Sept., and 19 Sept.

"Fruit free of defects (U.S. Department of Agriculture, 2005).

"Mixed model analysis of variance in SAS (version 9.3; SAS Institute) and Fisher's least significant difference means separation were performed on the data set. The percentage of marketable peppers was arcsine square root transformed. For the Tennessee data, all yield measurements were rank transformed. Untransformed values are reported. Values within a column with a letter in common are not significantly different; lowercase letters $=P<0.05$, uppercase letters $=P<0.01$.

Table 5. Mean U.S. Department of Agriculture size grade distribution of marketable 'Aristotle' bell peppers harvested from screened field plots and unscreened control plots at the University of Kentucky Horticulture Research Farm and the University of Tennessee Organic Crops Unit during 2013 and 2014.

\begin{tabular}{|c|c|c|c|c|c|c|}
\hline \multirow[b]{2}{*}{ Treatment $^{\mathrm{z}}$} & \multicolumn{3}{|c|}{ Kentucky } & \multicolumn{3}{|c|}{ Tennessee $^{\mathrm{x}}$} \\
\hline & Fancy (no.) ${ }^{\mathrm{w}}$ & No. 1 (no.) ${ }^{w}$ & No. $2{\text { (no. })^{\mathrm{w}}}$ & Fancy (no.) & No. 1 (no.) & No. 2 (no.) \\
\hline $1 / 25$-inch fine mesh & 15.7 & $21.8 \mathrm{~B}^{\mathrm{v}}$ & 7.7 & $1.3 \mathrm{~A}$ & $11.9 \mathrm{~A}$ & 7.1 \\
\hline $1 / 6$-inch mesh & 14.0 & $20.3 \mathrm{~B}$ & 6.9 & $1.0 \mathrm{~A}$ & $7.9 \mathrm{~B}$ & 8.1 \\
\hline No screen & 18.5 & $29.3 \mathrm{~A}$ & 9.3 & $0.2 \mathrm{~B}$ & $5.0 \mathrm{C}$ & 10.4 \\
\hline $\begin{array}{l}P ; \mathrm{df} \text { (numerator, } \\
\quad \text { denominator); } \mathrm{F}\end{array}$ & $\begin{array}{c}P=0.56 \\
3,110 ; 0.68\end{array}$ & $\begin{array}{c}P=0.01 \\
3,110 ; 3.87\end{array}$ & $\begin{array}{c}P=0.41 \\
3,110 ; 0.96\end{array}$ & $\begin{array}{c}P=0.006 \\
3,131.5 ; 4.37\end{array}$ & $\begin{array}{c}P<0.001 \\
3,130.6 ; 8.59\end{array}$ & $\begin{array}{c}P=0.82 \\
3,131.7 ; 0.30\end{array}$ \\
\hline
\end{tabular}

${ }^{\mathrm{z}} 1$ inch $=2.54 \mathrm{~cm}$.

${ }^{y}$ Harvests conducted 15-17 July, 30 July, and 12 Aug. 2013 and on 8-10 July, 22-23 July, and 12-13 Aug. 2014.

${ }^{x}$ Harvests conducted 30 July, 13 Aug., 27 Aug., and 10 Sept. 2013 and on 17 July, 31 July, 14 Aug., 28 Aug., 10 Sept., and 19 Sept.

${ }^{w}$ Fancy $=$ without defect and with diameter $\geq 3$ inches and length $\geq 3.5$ inches; 1 inch $=2.54 \mathrm{~cm} ;$ No. $1=$ without defect and with diameter $\geq 2.5$ inches and length $\geq 2.5$ inches; No. 2 = without defect and with diameter $<2.5$ inches and length $<2.5$ inches.

${ }^{v}$ Mixed model analysis of variance in SAS (version 9.3; SAS Institute) and Fisher's least significant difference means separation were performed on the data set. For the Tennessee data, all size classes were rank transformed due to unequal variance and normality issues. Untransformed means are reported. Means within a column followed by the same letter are not significantly different; lowercase letters $=P<0.05$, uppercase letters $=P<0.01$.

of second and third instar stink bugs, such as assassin bugs (Reduviidae), which have been observed attacking stink bug nymphs (Lee et al., 2013a). Because the screens were initially constructed in the field early in the growing season before the peppers flowered and became attractive to brown marmorated stink bug (Lee et al., 2013a), it is unlikely that stink bugs entered the plots at this time. However, when the screens were opened several times over the summer to retrieve yellow sticky cards and harvest peppers, some stink bugs could have entered the plots at those times, subsequently causing damage to the fruit.

Visual counts of stink bugs inside the plots were low at both locations, despite relatively high levels of stink bug injury. The low counts could be attributed to behavioral characteristics of the brown marmorated stink bug, such as its dropping behavior in response to being approached (Lee et al., 2013b) or their higher levels of activity at night (Nielsen and Hamilton, 2009) when visual sampling did not occur. Also, the dense environment inside the plots may have decreased the chances of visually identifying stink bugs. More reliable sampling methods for the brown marmorated stink bug such as sweep net and beat-net sampling (Quarles, 2014) were not used in this study due to space limitations inside the cages and the need to protect the peppers from physical injury; however, because visual counts proved to be highly ineffective for sampling this pest, more reliable sampling methods should be used for other brown marmorated stink bug studies whenever possible.

The incidence of chewing injury at the Kentucky site within the finer mesh plots was reduced, though the higher incidence of this type of injury within the 1/6-inch mesh plots indicates that chewing insects may be able to enter screens with wider meshes. Insects observed causing the chewing injury included spotted cucumber beetle (Diabrotica undecimpunctata) and weevils (Curculionidae). All of the screened plots at the Kentucky site significantly reduced sunscald injury by shading the peppers from harmful levels of sunlight. However, the screens were not successful at reducing other cosmetic defects caused by adverse weather, bacteria, and fungal diseases, which were accounted for at the Tennessee site.

The smaller yield and weight of peppers in the screened plots at the Kentucky site are possibly due to the overshading of the pepper plants by the screens (Ajwang et al., 2002), resulting in lower fruit production than the plants in the unscreened plots. Though this overshading trend 
was observed at the Kentucky site, the yields produced between the treatment plots at the Tennessee site were not significantly different from one another. However, all of the screened plots produced a higher percentage of marketable fruit than the unscreened plots at the Kentucky site. Although the unscreened plots produced more fruit, a large portion of the peppers were exposed to weather and insect injury, reducing the percentage of marketable peppers. In Tennessee, the fine-mesh plots produced the most marketable peppers by weight and the highest percentage of marketable fruit. Pressure from pests was possibly high enough in this region that they were able to enter the medium-sized mesh plots, but were still excluded from the fine-mesh plots. Also, the white finemesh screens likely allowed more sunlight to reach the plants than their darker counterparts, allowing the plants to produce larger yields (Ajwang et al., 2002).

The trend at the Kentucky site toward more number 1 grade peppers in the unscreened plots than in the screened plots is possibly a result of the overshading by the screens that cause the plants to produce smaller fruit (Ajwang et al., 2002). However, this trend was the opposite for the Tennessee site, which produced more number 1 grade peppers in the finer mesh plots and also observed a trend toward more fancy grade peppers being produced in the screened plots. The screens in this environment likely sheltered the plants from insect injury, allowing them to produce larger fruit in plots with finer meshes that excluded the most insects. The Tennessee site used the white fine-mesh treatments during both years, unlike the Kentucky site, which used a black, fine mesh during 2013. The black fine-mesh plots in Kentucky produced significantly smaller fruit than the other treatments in 2013; however, the white fine-mesh plots produced larger fruit in 2014 along with more fancy grade peppers than the other treatments. Possibly the 'Aristotle' pepper used in this study may be unable to compensate for shading effects like other pepper varieties (Jaimez and Rada, 2006; Kitta et al., 2014) and consequently produces smaller fruit under dark screens.

Large screen houses in the field that protect vulnerable crops from stink bugs could be an economical option for the deployment of these screens by organic growers. However, these screen treatments should be reevaluated after their incorporation into screen houses to determine if they retain the same exclusionary properties at a more industrial scale. Other types of crops should also be tested under the screens to determine if their reactions to the screen treatments differ from the responses of pepper plants.

In Kentucky, medium size screens allowed the entry of higher numbers of natural enemies than the fine screens and dark, fine-mesh screens negatively impacted crop yield by overshading the plants. If screens incorporated into large screen houses produce similar results in areas with small populations of brown marmorated stink bug, growers could use wider, lightcolored screens that allow for the entry of natural enemies to control small pests that are able to enter the screen house and reduce the amount of shading on the crops.

In Tennessee, where brown marmorated stink bug populations were large, white fine-mesh screens produced higher yields than other treatments by protecting the peppers from insect damage. Growers in areas with larger populations of brown marmorated stink bug may benefit more from finer, light-colored mesh screens that exclude a broader size range of pests that could damage the fruit.

Selecting the appropriate type of screen to protect crops throughout the growing season in areas with different densities of brown marmorated stink bug could potentially provide greater protection than current organic control options against this pest. In some cases, the use of finemesh screen houses could even potentially be more cost-effective than large amounts of pesticides used by conventional growers in areas with high brown marmorated stink bug densities. With support from further research, barrier screens could be successfully integrated into growing systems and serve as an effective control option against the brown marmorated stink bug.

\section{Literature cited}

Ajwang, P., H. Tantau, and C. Von Zabeltitz. 2002. Insect screens for integrated production and protection in greenhouses:
A review of the physical and technical basics. Gartenbauwissenschaft. 67:45-49.

Ausher, R. 1997. Implementation of integrated pest management in Israel. Phytoparasitica 25:119-141.

Cerkauskas, R. 2004. Bacterial soft rot. AVRDC-The World Vegetable Center Fact Sheet. 4:1-2.

Fukuoka, T., H. Yamakage, and T. Niiyama. 2002. Sucking injury to vegetables by the brown marmorated stink bug, Halyomorpha halys (Stal). Annu. Rpt. Soc. Plant Protection North Jpn. 53:229-231.

Funayama, K. 2008. Seasonal fluctuations and physiological status of Halyomorpha halys (Stal) (Heteroptera: Pentatomidae) adults captured in traps baited with synthetic aggregation pheromone of Plautia crossota stali Scott (Heteroptera: Pentatomidae). Jap. J. Appl. Entomol. Zool. 52:69-75.

Hamilton, G. 2011. Year brown marmorated stink bug detected by state. 4 Sept. 2015. <http://www.stinkbug-info.org/ index.php/insect $/ \mathrm{Pl}>$.

Hoebeke, E.R. and M.E. Carter. 2003. Halyomorpha halys (Stal) (Heteroptera: Pentatomidae): A polyphagous plant pest from Asia newly detected in North America. Proc. Entomol. Soc. Wash. 105:225-237.

Jaimez, R.E. and F. Rada. 2006. Flowering and fruit production dynamics of sweet pepper (Capsicum chinense Jacq) under different shade conditions in a humid tropical region. J. Sustain. Agr. 27:97-108.

Kamminga, K.L., D.A. Herbert, Jr., T.P. Kuhar, S. Malone, and H. Doughty. 2009. Toxicity, feeding preference, and repellency associated with selected organic insecticides against Acrosternum hilare, and Euschistus servus (Hemiptera: Pentatomidae). J. Econ. Entomol. 102:1915-1921

Kamminga, K.L., A.L. Koppel, D.A. Herbert, Jr., and T.P. Kuhar. 2012. Biology and management of the green stink bug. J. Integrated Pest Mgt. 3:Cl-C8.

Kitta, E., N. Katsoulas, A. Kandila, M.M. Gonzalez-Real, and A. Bailie. 2014. Photosynthetic acclimation of sweet pepper plants to screenhouse conditions. HortScience 49:166-172.

Kuhar, T.P., K.L. Kamminga, J. Whalen, G.P. Dively, G. Brust, C.R.R. Hooks, G. Hamilton, and D.A. Herbert. 2012. The pest potential of brown marmorated stink bug on vegetable crops. Plant Health Prog. 0523-0501.

Lee, D.H., A.L. Nielsen, and T.C. Leskey. 2014. Dispersal capacity and behavior of 
nymphal stages of Halyomorpha halys (Hemiptera: Pentatomidae) evaluated under laboratory and field conditions. J. Insect Behav. 27:639-651.

Lee, D.H., B.D. Short, S.V. Joseph, J.C. Bergh, and T.C. Leskey. 2013a. Review of the biology, ecology, and management of Halyomorpha halys (Hemiptera: Pentatomidae) in China, Japan, and the Republic of Korea. Environ. Entomol. 42:627-641.

Lee, D.H., S.E. Wright, and T.C. Leskey. 2013 b. Impact of insecticide residue exposure on the invasive pest, Halyomorpha halys (Hemiptera: Pentatomidae): Analysis of adult mobility. J. Econ. Entomol. 106:150-158.

Leskey, T. 2014. Where is BMSB? 23 Apr. 2015. <http://www.stopbmsb.org/ where-is-bmsb/>.

Leskey, T.C., G.C. Hamilton, A.L. Nielsen, D.F. Polk, C.R. Rodriguez-Saona, J.C. Bergh, D.A. Herbert, T.P. Kuhar, D. Pfeiffer, and G.P. Dively. 2012a. Pest status of the brown marmorated stink bug, Halyomorpha halys in the USA. Outlooks Pest Mgt. 23:218-226.

Leskey, T.C., B.D. Short, B.R. Butler, and S.E. Wright. 2012b. Impact of the invasive brown marmorated stink bug, Halyomorpha halys (Stal), in mid-Atlantic tree fruit orchards in the United States: Case studies of commercial management. Psyche (Stuttg.) 2012:1-14.
Nielsen, A.L. and G.C. Hamilton. 2009. Seasonal occurrence and impact of Halyomorpha halys (Hemiptera: Pentatomidae) in tree fruit. J. Econ. Entomol. 102:1133-1140.

Nielsen, A.L., G.C. Hamilton, and D. Matadha. 2008. Developmental rate estimation and life table analysis for Halyomorpha halys (Hemiptera: Pentatomidae). Environ. Entomol. 37:348-355.

Owens, D.R., D.A. Herbert, G.P. Dively, D.D. Reisig, and T.P. Kuhar. 2013. Does feeding by Halyomorpha halys (Hemiptera: Pentatomidae) reduce soybean seed quality and yield? J. Econ. Entomol. 106:1317-1323.

Quarles, W. 2014. IPM for the brown marmorated stink bug. IPM Practioner 34:1-8.

Rice, K.B., C.J. Bergh, E.J. Bergmann, D.J. Biddinger, C. Dieckhoff, G.P. Dively, H. Fraser, T. Gariepy, G. Hamilton, and T. Haye. 2014. Biology, ecology, and management of brown marmorated stink bug (Hemiptera: Pentatomidae). J. Integrated Pest Mgt. 5:Al-Al3.
Saxton, A. and B. Auge. 2014. Stats design and analysis web guide. $23 \mathrm{Apr}$. 2015. <http://dawg.utk.edu/>.

Talamas, E.J., M.V. Herlihy, C. Dieckhoff, K.A. Hoelmer, M.L. Buffington, M. Bon, and D.C. Weber. 2015. Trissolcus japonicus (Ashmead) (Hymenoptera, Scelionidae) emerges in North America. J. Hymenopt. Res. 43:119-128.

Taylor, R.A.J., S. Shalhevet, I. Spharim, M.J. Berlinger, and S. Lebiush-Mordechi. 2001. Economic evaluation of insectproof screens for preventing tomato yellow leaf curl virus of tomatoes in Israel. Crop Prot. 20:561-569.

U.S. Department of Agriculture (USDA). 2005. United States standards for grades of sweet peppers. 18 Dec. 2015 . <http:// www.ams.usda.gov/sites/default/files / media/Sweet_Pepper_Standard\%5B1\% 5D.pdf $>$.

Zhu, G.P., W.J. Bu, Y.B. Gao, and G.Q. Liu. 2012. Potential geographic distribution of brown marmorated stink bug invasion (Halyomorpha halys). PLoS One 7:10. 